\title{
Building a molecular typing protocol for rs1801133 based on real-time PCR HRM technique
}

\author{
Tran Thi Nhut Linh, Nguyen Thi Huynh My, Le Nguy Hoang Linh, Le Dang Khoa, Nguyen \\ Hoang Nhat Minh, Le Quang Tri, Nguyen Hoang Chuong
}

\begin{abstract}
-rs1801133 is a single nucleotide polymorphism (SNP) located in the sequence of MTHFR on human chromosome 1 . The alleles of this SNP affect the activity of the MTHFR enzyme. People bearing C/T genotype have $66 \%$ activity of MTHFR while people with $\mathbf{T} / \mathrm{T}$ genotype have only 25\% activity. These reduced activities of MTHFR cause homocysteinemia. There are several publications on the relationship between homocysteinemia and human diseases such as cardiovascular disease, neurological diseases, abnormal fetus, infertility and cancer. In this study, we built a molecular protocol for genotyping rs1801133 using real-time PCR HRM technique. This protocol could be used for diagnosis of molecular mechanism of homocysteinemia causing the mentoned above diseases as well as for the study of the relationship between rs1801133 and other human diseases. We successfully designed the primer pairs for genotyping and nucleotide sequencing rs1801133 by real-time PCR HRM and Sanger sequencing method. We also examined the optimal $\mathrm{MgCl}_{2}$ concentration for clear differentiation of three rs1801133 genotypes. Performance characteristics of the real-time PCR HRM protocol included of specificity, repeatability, reproducibility was evaluated and it showed good results. Comparison of genotyping results of rs1801133 between the realtime PCR HRM method and the Sanger nucleotide sequencing method showed good concordances. Finally, this real-time PCR HRM protocol for rs1801133 genotyping was applied on 100 human DNA samples to evaluate the clinical utility of the protocol.
\end{abstract}

Received: 05-01-2017, accepted :14-08-2017, published: 12-9-2018

Author: Tran Thi Nhut Linh, Nguyen Thi Huynh My, Le Nguy Hoang Linh - Center for Research and Application in Bioscience, Le Dang Khoa, Nguyen Hoang Nhat Minh - My Duc Hospital, Le Quang Tri - 7A Hospital, Nguyen Hoang Chuong - VNUHCM, University of Sciencenhchuong@hcmus.edu.vn
Index Terms-rs1801133, real-time PCR HRM,
SNP

\section{INTRODUCTION}

$M$ Ethylenetetrahydrofolate reductase (MTHFR) is an enzyme that is involved in the methylation cycle in the human body. This enzyme is located on chromosome 1 at the position $1 \mathrm{p} 63.3$ [1]. The function of this enzyme is to convert 5,10-methylenetetrahydrofolate to 5methylenetetrahydrofolate. In turn, 5methylenetetrahydrofolate is used as a substrate for converting homocysteine to methionine by the methionine synthase enzyme [2].

The MTHFR gene has many variants in the nucleotide sequence due to different SNPs located in the nucleotide sequence of the gene. These different variants of the gene affect the methylenetetrahydrofolate reduction of MTHFR in which the C677T variant (rs1801133) was most studied. This variant has two alleles, cytosine (C) and thymine (T). C is at nucleotide 677 coded for alanine whereas $\mathrm{T}$ is at the same nucleotide coded for valine resulting in the decrease in 5,10methylenetetrahydrofolate reductase activity of the MTHFR enzyme [3]. MTHFR requires the lavin adenine dinucleotide (FAD) cofactor for its activity and studies have shown that the human recombinant MTHFR protein with the 677T variant lost its $\mathrm{FAD}$ cofactor three times much more than the MTHFR with the $677 \mathrm{C}$ variant $[4$, 5].

MTHFR depletion of the 677T variant resulted in elevated levels of homocysteine in the blood. Homocysteine is an amino acid that does not constitute normal proteins. It is a homologous 
form of the cysteine amino acid but differs from the $-\mathrm{CH}_{2}$ moiety [6]. High levels of homocysteine in the blood are often associated with increased cardiovascular risk, neurological diseases, miscarriage, cancer, infertility in different populations and races [7-11]. In addition, this SNP is associated with the prognosis of treatment with anticancer drugs. Specifically, the $677 \mathrm{~T}$ variant has a good response to 5-fluorouracil in the treatment of colorectal cancer and breast cancer. However, if methotrexate is used in the treatment of breast cancer, the $677 \mathrm{~T}$ variant will have a high risk of side effects as well as reduced effectiveness the of treatment [12].

Thus, the identification of the rs1801133 genotype is necessary not only for the study of this SNP involving in human diseases but also for the prognosis of treatment with anti-cancer drugs as well as identification of molecular causes of some human diseases. Another application of rs1801133 genotyping is the prediction of the risk of neonatal illness [13]. In fact, there are many molecular protocols/commercial kits for genotyping rs1801133. Technically, these protocol/kits are based on molecular techniques such as PCR-RFLP [14], PCR-sequencing [15], real-time PCR with specific Taqman probes [16], molecular hybridization with hairpin probes [17] and realtime PCR HRM [18]. The last is also the technique chosen for rs 1801133 genotyping in this study.

According to our present understanding, no molecular protocols/kits have been developed for rs1801133 genotyping in Vietnam. This is why we wanted to build a molecular protocol for genotyping rs1801133 based on real-time PCR HRM technique. The molecular protocol will serve for fundamental research to examine the relationship between this SNP and human diseases in Vietnamese population. In addition, it can be used for the diagnosis of hyperhomocysteinemia as well as the prognosis of cancer treatment with specific medications as described above.

\section{MATERIALS AND METHODS}

\section{Reagents}

The human DNA samples and the bacterial strains were supplied by Center for Research and Application in Bioscience (Ho Chi Minh city, Vietnam). All the chemical reagents for PCR, realtime PCR HRM, agarose gel electrophoresis were purchased from Bioline (UK), Merck (Germany) and Sigma (USA). The nucleotide sequencing kit was supplied by Applied Biosystems (USA). The primer were synthesized and supplied by Phu Sa Biochem (Vietnam).

\section{Primer design}

DNA fragment surrounding rs1801133 was obtained from GenBank and was used as the template for primer design. Two primer pairs were designed using the AnnHyb software in which one pair for genotyping rs1801133 by real-time PCR HRM and the other for nucletide sequencing of this SNP. The oligo characteristics of these primers in terms of $\mathrm{Tm}, \% \mathrm{GC}$, free energy of secondary structures were checked with OligoAnalyzer sofware to assure the good performance in PCR. Finally, the ability to bind specifically to the DNA region containing rs1801133 of these primers was confirmed using Primer-Blast software.

\section{Real-time PCR HRM}

The real-time PCR reaction was set up in 0.1 $\mathrm{mL}$ tube with following components: real-time PCR buffer containing the fluorescent dye Eva Green, dNTP, Taq polymerase, the primer pair CN5-CN6, and the DNA template. The reaction program was initated at $95^{\circ} \mathrm{C}$ for 120 seconds followed by 40 cycles of $95^{\circ} \mathrm{C}$ for 10 seconds, $60^{\circ} \mathrm{C}$ for 10 seconds and $72^{\circ} \mathrm{C}$ for 10 seconds. The HRM analysis on PCR product was started at 60 to $97^{\circ} \mathrm{C}$ with $0.1^{\circ} \mathrm{C}$ increment. The results were analyzed using MyGo-Pro PCR software based on the melting curve shape on the Normalized Melting Curves and melting point $\mathrm{Tm}$ of the amplified product.

\section{Nucleotide sequencing}

The PCR products containing rs1801133 were obtained by PCR with the CN3-CN4 primer pair. They were purified before being labeled with approriate fluorescents. Next, the labeled PCR products were analyzed on ABI 3500 genetic analyzer. The nucleotide sequence of the target PCR product was analyzed based on the fluorescence signals. This sequence was compared to the original sequence containing rs1801133 on GenBank. In addition, the fluorescence signal at rs 1801133 position was analyzed to confirm the genotype of rs1801133. 


\section{Verification of analytical specificity}

Analytical specificity of the real-time PCR HRM protocol was investigated using real-time PCR with the primer pair for rs 1801133 genotyping on genetic materials from various microorganisms that may appear simultaneously on human body. If the rs1801133 genotyping protocol is positive for human DNA and negative on other genetic materials, the rs1801133 genotyping protocol is completely specific for rs1801133 in humans.

\section{Assessment of precisions}

The rs1801133 genotyping protocol was repeated several times in the same test conditions on the same day on the samples containing known $\mathrm{C} / \mathrm{C}, \mathrm{C} / \mathrm{T}$ and $\mathrm{T} / \mathrm{T}$ genotypes to check the repeatability. Also, the rs1801133 genotyping protocol was repeated several times during various test conditions on samples containing known $\mathrm{C} / \mathrm{C}$, $\mathrm{C} / \mathrm{T}$ and $\mathrm{T} / \mathrm{T}$ genotypes to check the reproducibility. The degree of deviation in the rs1801133 genotyping resulted on the samples was assessed using the value of CV (Coefficient of Variation) and the unit of calculation was expressed as percentage.

\section{RESULTS AND DISCUSSION}

\section{Oligonuclotide design}

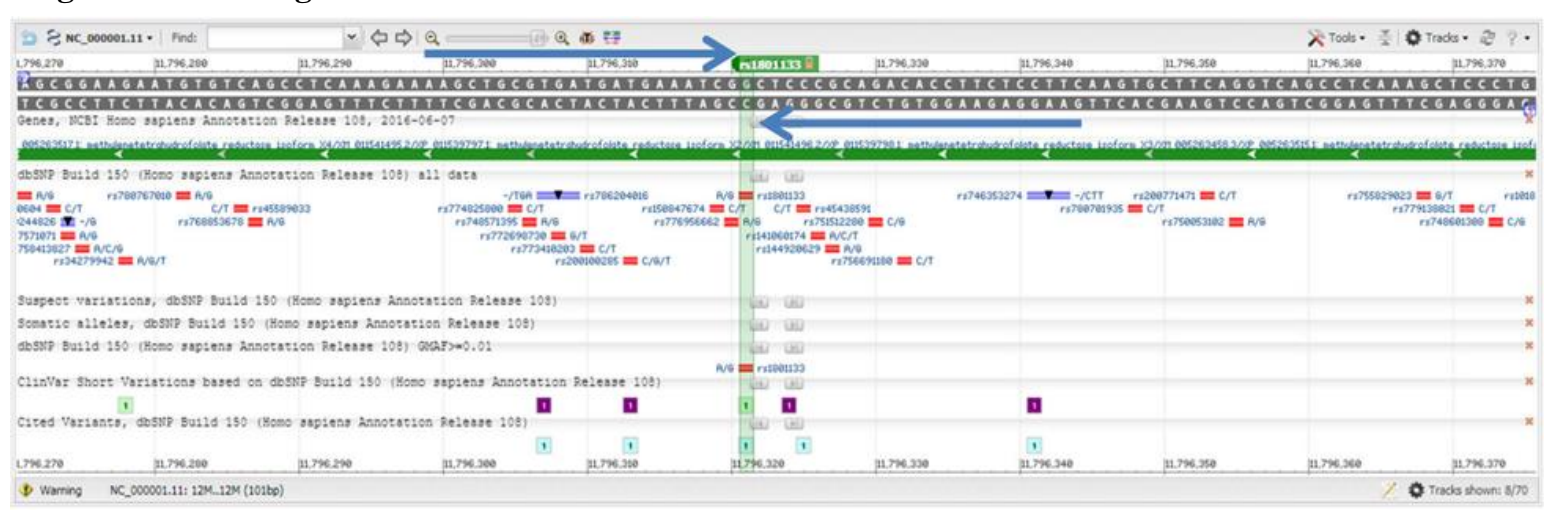

Fig. 1. The human DNA region containing rs1801133 and other surrounding SNPs symbolised by small rectangulars. The arrows represent the position of the CN5-CN6 primer pair

Table 1. Technical parameters of the designed primers

\begin{tabular}{|l|c|c|c|c|}
\hline \multirow{2}{*}{ Parameters } & \multicolumn{5}{c|}{ Primer } \\
\cline { 2 - 5 } & CN3 & CN4 & CN5 & CN6 \\
\hline Nucleotide & 20 & 19 & 20 & 20 \\
\hline GC content (\%) & 55 & 65 & 57.9 & 45 \\
\hline Tm $\left({ }^{\circ} \mathrm{C}\right)$ & 56.1 & 61.8 & 55.4 & 53.3 \\
\hline $\begin{array}{l}\text { Hairpin } \\
\text { (kcal/mole) }\end{array}$ & -1.38 & -0.22 & -0.56 & -0.15 \\
\hline $\begin{array}{l}\text { Self-dimer } \\
\text { (kcal/mole) }\end{array}$ & 4.74 & 3.61 & 3.61 & 6.34 \\
\hline $\begin{array}{l}\text { Hetero-dimer } \\
\text { (kcal/mole) }\end{array}$ & \multicolumn{2}{|c|}{4.67} & \multicolumn{3}{|c|}{3.61} \\
\hline
\end{tabular}

We designed the primer pair for genotyping rs1801133 by real-time HRM PCR and the primer CN3: 5' CTT TGA GGC TGA CCT GAA GC 3' CN4: 5' AGG ACG GTG CGG TGA GAG TG 3' CN5: 5' GAA GGA GAA GGT GTC TGC GGA G 3' - CN6: 5' AGC TGC GTG ATG ATG AAA TCG 3'

The CN5-CN6 primer pair was designed for genotyping rs1801133 and PCR product with this primer pair was 45 bp in size. The small size of 45 bp helps to avoid other SNPs in the proximity of rs1801133. Moreover, the CN5-CN6 primer pair occupies most of the nucleotide sequence of the PCR product except for the position of rs 1801133 resulting that different human DNAs containing rs1801133 will be distinguished merely at rs1801133 (Fig. 1).

In constrast, the $\mathrm{CN} 3-\mathrm{CN} 4$ primer pair was designed for sequencing rs 1801133 by Sanger technique and PCR product with this primer pair was $221 \mathrm{bp}$ in size. The next step, we checked the technical parameters of the primers such as Tm, the GC component, the free energy of the secondary structures using OligoAnalyzer software. The results were presented in Table 1 .

The results in Table 1 showed that the four primers met the specific requirements to work well in the PCR. Finally, we tested the theoretical specificity of these primers using Blast software. The results showed that the primers matched with the human DNA at the MTHFR gene (Data not shown). In conclusion, the designed primers were good for the subsequent experiments. 
Building the real-time PCR HRM for genotyping rs1801133
With the CN5-CN6 primer pair, a real-time PCR HRM reaction on six human DNA samples were built. The results were presented in Fig. 2.

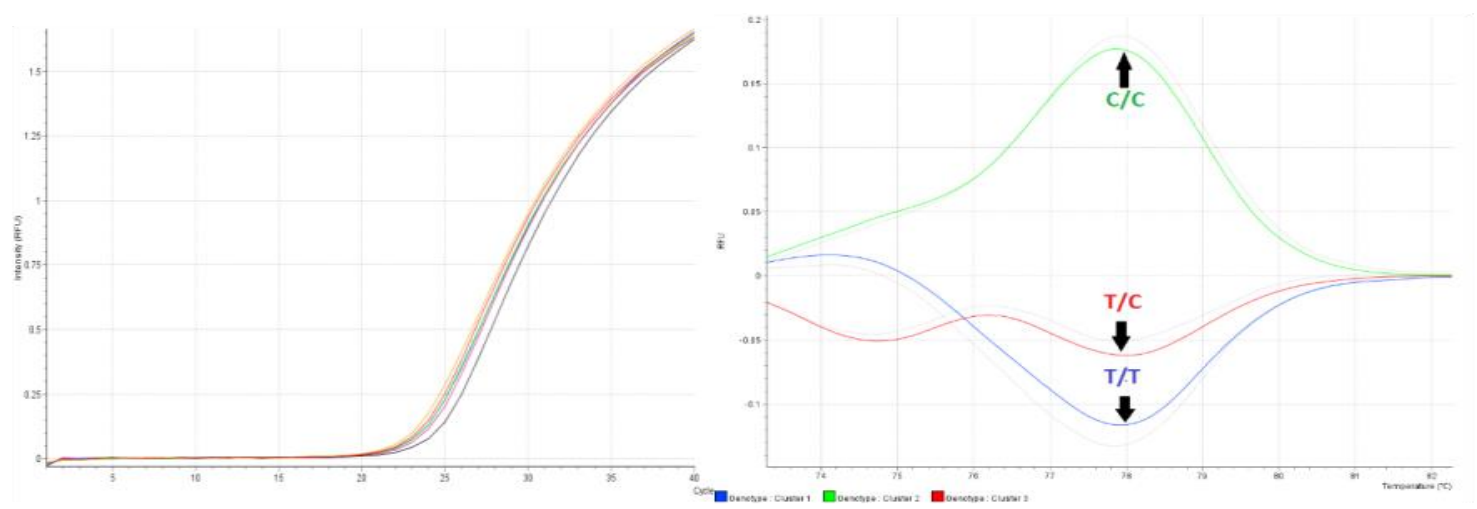

Fig. 2. The real-time PCR plus HRM results on six human DNA samples
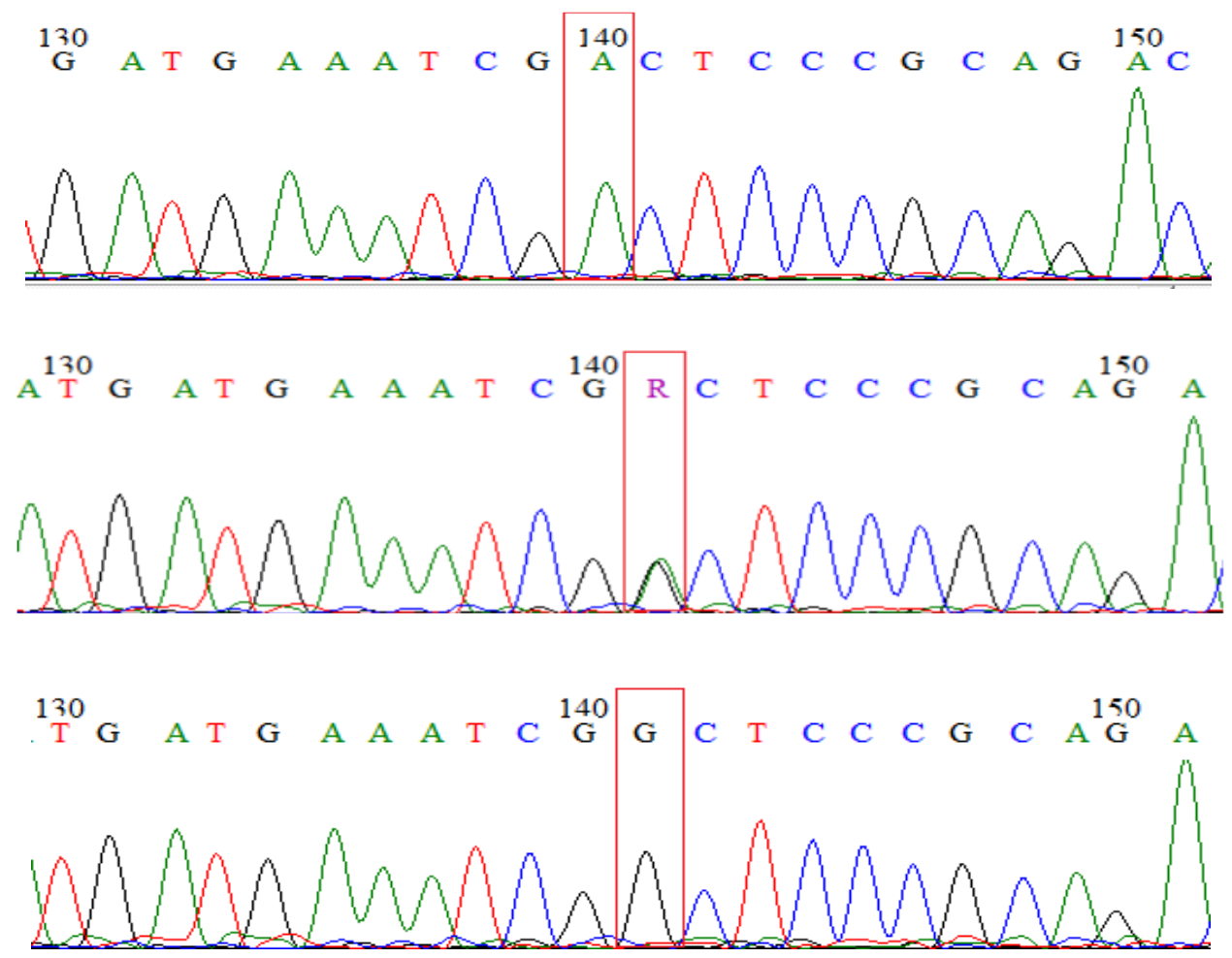

Fig. 3. Results of Sanger's nucleotide sequencing on three DNA samples containing C/C, C/T, and T/T genotypes of rs 1801133 . The sequencing results were shown in the reverse DNA strands

The results in Fig. 3 showed the occurrence of genotype contained a peak representing guanine. the peaks corresponding to the nucleotides of rs1801133. On the reverse strand, the sample containing the T/T genotype contained a peak of adenine, the sample containing genotype $\mathrm{C} / \mathrm{T}$ contain a double peak, representing adenine and Thus, the result of Sanger nucleotide sequencing confirmed that the rs 801133 genotyping results by real-time PCR HRM were accurate.

\section{Optimization of $\mathrm{MgCl}_{2}$ concentration} guanine, and the sample containing the $\mathrm{C} / \mathrm{C}$ 
$\mathrm{MgCl}_{2}$ is the major component that influences the melting temperature of PCR products when analyzed by HRM. Therefore, we investigated the optimum $\mathrm{MgCl}_{2}$ concentration for distinguishing three melting curve patterns corresponding to three genotypes $\mathrm{C} / \mathrm{C}, \mathrm{C} / \mathrm{T}$ and $\mathrm{T} / \mathrm{T}$ of $\mathrm{rs} 1801133$. In the
PCR master mix for real-time PCR HRM with the unknown concentration of $\mathrm{MgCl}_{2}$, we investigated the added $\mathrm{MgCl}_{2}$ concentrations as follows: $0 \mathrm{mM}$, $0.5 \mathrm{mM}, 1 \mathrm{mM}, 1.5 \mathrm{mM}, 2 \mathrm{mM}, 2.5 \mathrm{mM}$, and 3 $\mathrm{mM}$. The results of the optimization of $\mathrm{MgCl}_{2}$ concentration were shown in Fig. 4.

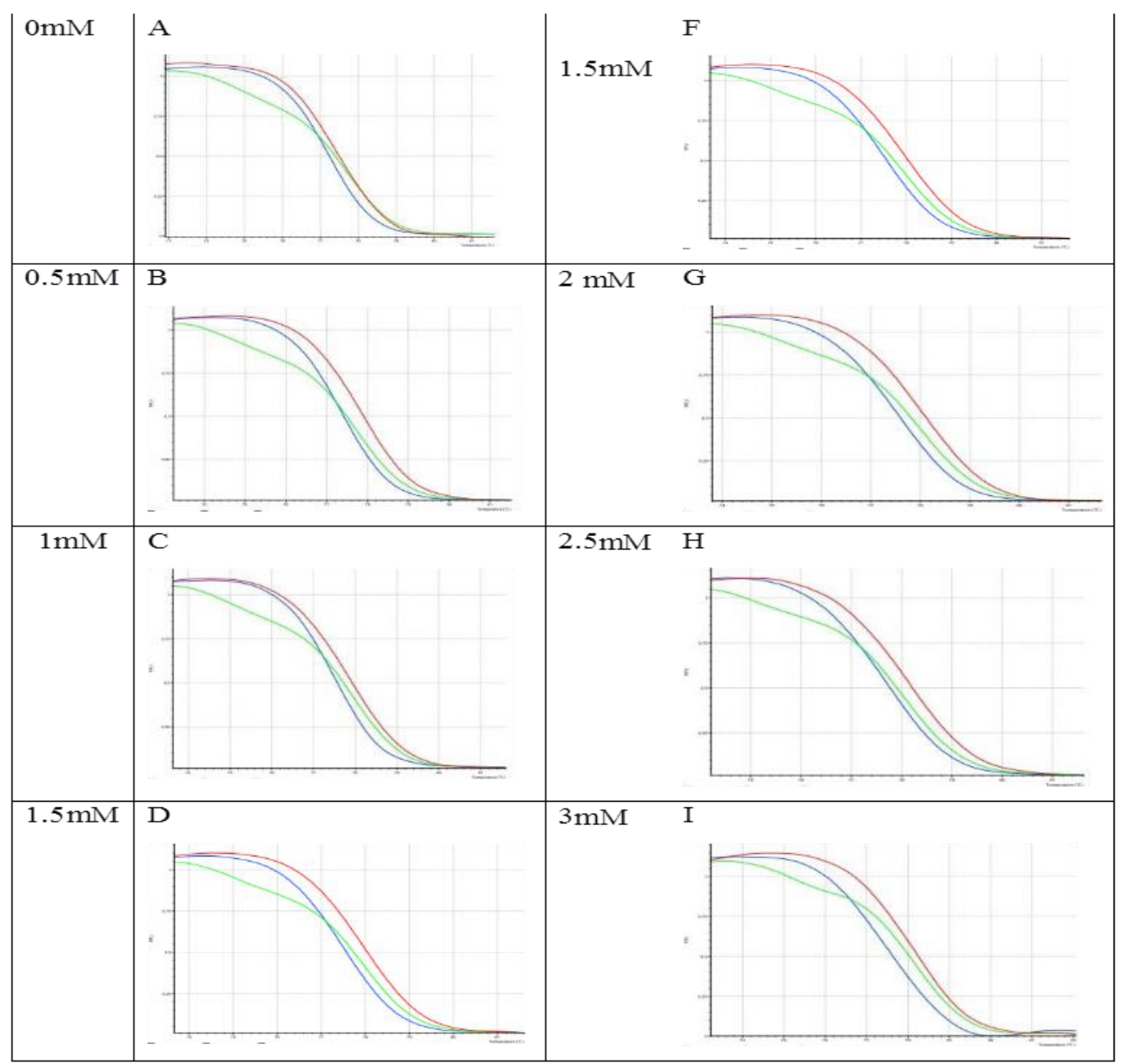

Fig. 4. Examination of the optimal $\mathrm{MgCl}_{2}$ concentration to distinguish three melting curves corresponding to the three genotypes $\mathrm{C} / \mathrm{C}, \mathrm{C} / \mathrm{T}$ and $\mathrm{T} / \mathrm{T}$ of rs 1801133

The results in Fig. 4 showed that the three melting curve genes corresponding to the three genotypes $\mathrm{C} / \mathrm{C}, \mathrm{C} / \mathrm{T}$ and $\mathrm{T} / \mathrm{T}$ of rs1801133 were more clearly distinguished when the $\mathrm{MgCl}_{2}$ concentrations increased. At the $\mathrm{MgCl}_{2}$ concentration of $3 \mathrm{mM}$, three melting curves were most distiguished and the Tm. With this result, the $3 \mathrm{mM}$ concentration was chose for subsequent studies.

\section{Analytical specificity of real-time PCR HRM protocol}

Analytical specificity of the real-time PCR HRM protocol was demonstrated by the selective amplification of the human DNA region containing rs 1801133 by the target primer pair. In this experiment, we investigated the selective amplification of the CN5-CN6 primer pair on the genetic material of various agents including human and bacteria (Escherichia coli, Staphylococcus aureeus, Pseudomonas aeruginosa, Shigella dysenteria, Vibrio cholera, Klebsiella рпиеитоniae) in the real-time PCR. The results of the selective amplification of the CN5-CN6 primer pair were presented in Fig. 5. 


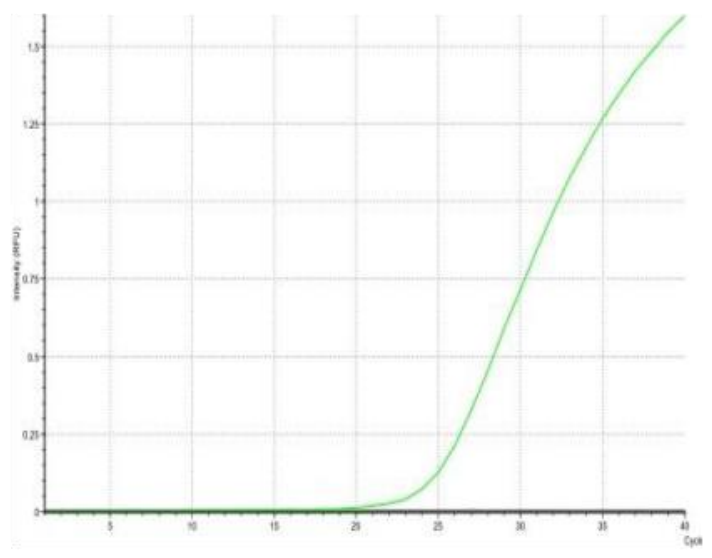

Fig. 5. Selective amplification of the CN5-CN6 primer pair on various genetic materials from human and bacteria

The results in Fig. 5 showed that only the human DNA sample gave the positive result in the real-time PCR reaction with the CN5-CN6 primer pair, whereas DNA samples from the bacteria produced negative results in the reaction with the same primer pair. To confirm the negative results in the real-time PCR reaction with the CN5-CN6 primer pair on the bacterial DNA samples were truly negative, we performed the PCR reaction with the 27F-1495R primer pair on these DNA samples. This is a primer pair specific for the $16 \mathrm{~S}$ rRNA gene of all eubacteria. Results showed that the DNA samples from $E$. coli, $S$. aureeus, $P$. aeruginosa, $S$. dysenteria, $V$. cholera, $K$. pneumoniae were positive for PCR with the 27F1495R primer pair (Data not shown). This result confirmed that the negative results in the real-time PCR reaction with the CN5-CN6 primer pair on the bacterial DNA samples were truly negative. Thus, the real-time PCR HRM protocol was specifically designed to genotype rs1801133 in human.

\section{Precisions}

We genotyped rs1801133 using the real-time PCR HRM protocol on three samples of $\mathrm{C} / \mathrm{C}, \mathrm{C} / \mathrm{T}$ and $T / T$ genotypes five times in the same experiment batch to measure the repeatability of the protocol. Also, we genotyped rs 1801133 using the real-time PCR HRM protocol on three samples of $\mathrm{C} / \mathrm{C}, \mathrm{C} / \mathrm{T}, \mathrm{T} / \mathrm{T}$ genotypes five times in five experiment batchs to measure the reproducibility of the protocol. The repeatability and reproducibility expressed by the coefficient of variation $(\mathrm{CV})$ and the $\mathrm{CV}$ values were calculated as percentage. The results were presented in Tables 2 and Table 3.

Table 2. Repeatability calculation of the real-time PCR HRM for genotyping rs1801133

\begin{tabular}{|c|c|c|c|}
\hline Repeat & $\mathrm{T} / \mathrm{T}$ & $\mathrm{C} / \mathrm{T}$ & $\mathrm{C} / \mathrm{C}$ \\
\hline 1 & 77.15 & 77.37 & 78.10 \\
\hline 2 & 77.08 & 77.42 & 78.17 \\
\hline 3 & 77.09 & 77.59 & 78.12 \\
\hline 4 & 77.03 & 77.29 & 78.11 \\
\hline 5 & 77.08 & 77.37 & 78.07 \\
\hline Average & 77.086 & 77.408 & 78.114 \\
\hline $\begin{array}{c}\text { Standard } \\
\text { deviation }\end{array}$ & 0.04277 & 0.11189 & 0.03646 \\
\hline \% CV & 0.05549 & 0.14454 & 0.04668 \\
\hline Total \% CV & \multicolumn{3}{|c}{0.08244} \\
\hline
\end{tabular}

Table 3. Reproducibility calculation of the real-time PCR HRM for genotyping rs 1801133

\begin{tabular}{|c|c|c|c|}
\hline Repeat & $\mathrm{T} / \mathrm{T}$ & $\mathrm{C} / \mathrm{T}$ & $\mathrm{C} / \mathrm{C}$ \\
\hline 1 & 77.13 & 77.31 & 77.74 \\
\hline 2 & 76.99 & 77.55 & 77.85 \\
\hline 3 & 76.99 & 77.4 & 77.83 \\
\hline 4 & 76.92 & 77.41 & 77.49 \\
\hline 5 & 76.98 & 77.4 & 77.65 \\
\hline Average & 77.06 & 77.41 & 77.71 \\
\hline $\begin{array}{c}\text { Standard } \\
\text { deviation }\end{array}$ & 0.07726 & 0.08619 & 0.14737 \\
\hline \%CV & 0.10026 & 0.11134 & 0.18964 \\
\hline Total \%CV & \multicolumn{3}{|l}{0.13375} \\
\hline
\end{tabular}

The CV value of the repeatability test of the real-time PCR HRM protocol was $0.08 \%$ and the reproducibility test results showed the $\mathrm{CV}$ value of $0.13 \%$. These $\mathrm{CV}$ values proved the high precision of the real-time PCR HRM protocol for genotyping rs 11077.

\section{Evaluating the real-time PCR HRM protocol on 100 human DNA samples}

We evaluated the performance of the real-time PCR HRM protocol for genotyping rs 1801133 on 100 human DNA samples which were given by the Center for Research and Applied Biology. The genotyping results were presented in Fig. 6.

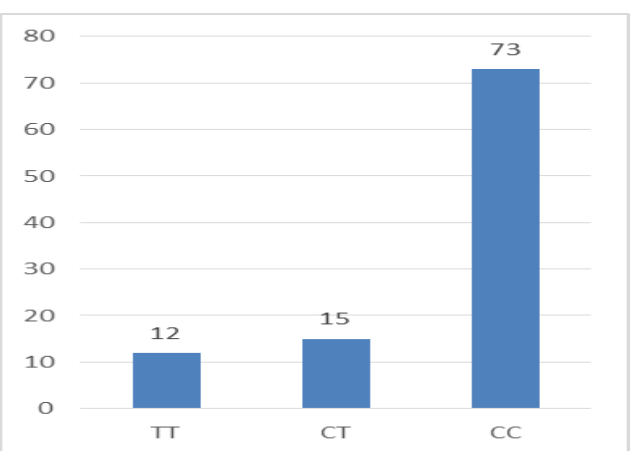

Fig. 6. rs1801133 genotyping results on 100 human DNA samples by the real-time PCR HRM protocol 
The results in Fig. 6 showed that there were 12 samples with genotype T/T, 15 samples with genotype $\mathrm{C} / \mathrm{T}$, and 73 samples containing genotype C/C. In addition, we performed the rs1801133 genotyping by Sanger nucleotide sequencing on 10 random samples out of the above 100 DNA samples for comparision. The rs 1801133 genotyping results on these 10 DNA samples matched well between the real-time PCR HRM protocol and the Sanger sequencing method (results not shown). In this study, the proportion of people carrying the unfavorable genotypes $\mathrm{T} / \mathrm{T}$ and $\mathrm{C} / \mathrm{T}$ accounted for $27 \%$ which shows the relatively high incidence of MTHFR defect in the vietnamese population. The genotype frequency of rs1801133 varies in different studies. Yu (2014) showed that the unfavorable genotypes $\mathrm{T} / \mathrm{T}$ and $\mathrm{C} / \mathrm{T}$ accounted for $12.9 \%$ in the Chinese population [19] while these unfavorable genotypes was $65 \%$ in Columbian population [20]. This genetic information is essential for health authorities to control MTHFR defected-related diseases in the community.

\section{CONCLUSION}

In this study, we built the rs1801133 genotyping protocol based on the real-time PCR HRM technique. The performance characteristics of the genotyping protocolin in the terms of analytical specificity, repeatability, reproducibility were good. Application of this genotyping protocol on 100 human DNA samples showed good results in comparison with the Sanger nucleotide sequencing method. The real-time PCR HRM for rs 1801133 genotyping in this study can be used as the molecular tool for association studies of this SNP in human diseases. In addition, the protocol could be developped as a molecular assay for the diagnosis of hyperhomocysteinemia and the prognosis of cancer treatment with specific medications.

Acknowledgement: This study was support by Science and Technology Incubator Youth Program, managed by the Center for Science and Technology Development, Ho Chi Minh Communist Youth Union. This study was conducted in the Center for Research and Application in Bioscience and we thanks the
Center for the given DNA samples and the bacterial strains.

\section{REFERENCES}

[1]. P. Goyette, J.S. Sumner, R. Milos, A.M. Duncan, D.S. Rosenblatt, R.G. Matthews, R. Rozen, "Human methylenetetrahydrofolate reductase: isolation of cDNA, mapping and mutation identification", Nature Genetics, 7, 2, 195-200, 1994.

[2]. E.E. Trimmer, "Methylenetetrahydrofolate reductase: biochemical characterization and medical significance", Current Pharmaceutical Design, 19, 14, 2574-93 , 2013.

[3]. P. Frosst, H.J. Blom, R. Milos, P. Goyette, C.A. Sheppard, R.G. Matthews, G.J. Boers, M. den Heijer L.A. Kluijtmans, L.P. van den Heuvel, "A candidate genetic risk factor for vascular disease: a common mutation in methylenetetrahydrofolate reductase", Nature Genetics, 10, 1, 111-3, 1995.

[4]. K. Yamada, Z. Chen, R. Rozen, R.G. Matthews, "Effects of common polymorphisms on the properties of recombinant human methylenetetrahydrofolate reductase", Proceedings of the National Academy of Sciences of the United States of America, 98, 26, 148538, 2001.

[5]. B. Schwahn, R. Rozen, "Polymorphisms in the methylenetetrahydrofolate reductase gene: clinical consequences", American Journal of Pharmacogenomics, 1, 3, 89-201, 2001.

[6]. J.E. McMurry, Organic Chemistry with Biological Applications: Chemistry, Organic Chemistry 3e. Cengage Learning, 2015.

[7]. L. Rashed, R.H. Abdel, M. AlKaffas, S. Ali, D. Kadry, S. Abdallah, "Studying the association between methylene tetrahdrofolate reductase (MTHFR) 677 gene polymorphism, cardiovascular risk and lichen planus", Journal of Oral Pathnlogy \& Medicine, doi: 10.1111/jop.12588. [Epub ahead of print], 2017

[8]. F.F. Roussotte, X. Hua, K.L. Narr, G.W. Small, Thompson PM, The C677T variant in MTHFR modulates associations between brain integrity, mood, and cognitive functioning in old age, Biological Psychiatry Cognitive Neuroscience and Neuroimaging, 2, 3, 280-288, 2017.

[9]. V. Rai, "Methylenetetrahydrofolate Reductase C677T Polymorphism and Recurrent Pregnancy Loss Risk in Asian Population: A Meta-analysis", Indian Journal of Clinical Biochemistry, 31, 4, 402-13, 2016.

[10]. T.Z. Lopes, A.P.G. Martins, C.H.N. Filho, M.M.C. Nunes, A.L.G. Dias, J.A.P. Júnior, J.V. Maniglia, J.L. Francisco, E.C. Pavarino, E.M.G. Bertollo, Role of MTHFR C677T and MTR A2756G polymorphisms in thyroid and breast cancer development, Genetics and 
Molecular Research, 15, 2, doi: 10.4238/gmr.15028222, 2016.

[11]. M.R. Safarinejad, N. Shafiei, S. Safarinejad, Relationship between genetic polymorphisms of methylenetetrahydrofolate reductase (C677T, A1298C, and G1793A) as risk factors for idiopathic male infertility, Reproductive Sciences, 18, 3, 304-15, 2011.

[12]. K.J. Sohn, R. Croxford, Z. Yates, M. Lucock, Y.I. Kim, "Effect of the methylenetetrahydrofolate reductase C677T polymorphism on chemosensitivity of colon and breast cancer cells to 5-fluorouracil and methotrexate", Journal of the National Cancer Institute, 96, 2, 134-44, 2004.

[13]. L.V. Yaliwal, M.R. Desai, "Methylenetetrahydrofolate reductase mutations, a genetic cause for familial recurrent neural tube defects", Indian Journal of Human Genetics, 18, 1, 122-124, 2012.

[14]. T. Deeparani, M.R. Pillai, T. Elavazhagan, Detection of MTHFR C677T and A1298C gene polymorphism in congenital heart disease. Middle-East Journal of Scientific Research 4, 2, 127-132, 2009.

[15]. E.S.W.H. Chehadeh, Jelinek HF, Al Mahmeed WA, Tay GK, Odama UO, Elghazali GEB, and Al Safar HS, Relationship between MTHFR C677T and A1298C gene polymorphisms and complications of type 2 diabetes mellitus in an Emirati population, Meta Gene, 9, 70-75, 2016.

[16]. H. Xu, C. Liu, Q. Wang, Plaque image characteristics, hyperhomocysteinemia, and gene polymorphism of homocysteine metabolism-related enzyme (MTHFR C677T) in acute coronary syndrome, Cell Bichemistry and Biophysics, 66, 2, 403-7, 2013.

[17]. Q. Chen, Y. Sun, L. Zhang, K. Deng, H. Xia, H. Xing, Y. Xiang, B. Ran, M. Zhang, X. Xu, W. Fu, Detection of C677T mutation of MTHFR in subject with coronary heart disease by hairpin probe with enzymatic color on microarray, Biosensors \& Bioelectronics, 28, 1, 84-90, 2011.

[18]. W. Ying, Z. Haiyan, Y. Shuying, Z. Kun, W. Hui, D. Rui, Y. Xiaomeng, L. Yi, M. Yanhui, Evaluation of high resolution melting for $\mathrm{mthfr}$ c677t genotyping in congenital heart disease, Plos One, 11, 3, e0151140 2016.

[19]. K.K. Yu, "Research of relationship between genes in folate metabolic pathway and congenital heart disease", Taishan Medical University, 2014.

[20]. C.R. Sanchez, A.G. Gutierrez, P.E. Gomez, CasasGomez MC, Briceno I, C677T (rs1801133) MTHFR gene polymorphism frequency in columbian population, Columbia Medica, 46, 2, 75-79, 2015. Pathol. 171(2): 386-395, 2007. 


\title{
Xây dựng quy trình phân type rs 1801133 dựa trên kỹ thuật real-time HRM
}

\author{
Trần Thị Nhựt Linh ${ }^{1}$, Nguyễn Thị Huỳnh $\mathrm{My}^{1}$, Lê Ngụy Hoàng Linh ${ }^{1}$, Lê Đăng Khoa ${ }^{2}$, \\ Nguyễn Hoàng Nhất Minh ${ }^{2}$, Lê Quang Trî́ ${ }^{3}$, Nguyễn Hoàng Chương ${ }^{4}$ \\ ${ }^{1}$ Trung tâm Nghiên cứu và Ửng dụng Sinh học, ${ }^{2}$ Bệnh Viện Mỹ Đức, ${ }^{3}$ Bệnh Viện 7A, \\ ${ }^{4}$ Trường Đại học Khoa học Tự nhiên, ĐHQG-HCM \\ Tác giả liên hệ: nhchuong@hcmus.edu.vn
}

Ngày nhận bản thảo: 05-01-2017, ngày chấp nhận đăng: 14-08-2017, ngày đăng: 12-09-2018

\begin{abstract}
Tóm tắt—rs1801133 là một đa hình đơn nucleotide nằm trên gene MTHFR thuộc nhiễm sắc thể số 1 ở người. Các allene của SNP này hưởng tới hoạt tính của enzyme MTHFR. Người mang genotype $C / T$ của SNP này có hoạt tính enzyme bị giảm còn $66 \%$ trong khi người mang genotype $T / T$ có hoạt tính bị giảm còn 25\%. Khi hoạt tính enzyme MTHFR giảm sẽ dẫn đến tình trạng gia tăng homocysteine trong máu. Có rất nhiều bằng chứng về sự liên quan giữa tình trạng gia tăng homocysteine và các bệnh ở người như bệnh tim mạch, thần kinh, bất thường thai nhi, vô sinh, ung thư. Trong nghiên cứu này, chúng tôi xây dựng một quy trình phân tử nhằm phân type rs1801133 sử dụng kỹ thuật real-time HRM. Quy trình này có thể được sử dụng để chẩn đoán nguyên nhân phân tử của chứng tăng homocysteine trong máu của các chứng bệnh đã đề cập ở trên. Ngoài ra, nó cũng được sử dụng như một công cụ để nghiên cứu sự liên quan
\end{abstract}

giữa SNP này với các chứng bệnh khác ở người. Chúng tôi đã thiết kế thành công các cặp primer nhằm phân type rs1801133 cũng như để giải trình tự nucleotide SNP này, cũng như đã khảo sát nồng độ $\mathrm{MgCl}_{2}$ thích hợp để phân biệt 3 dạng genotype tương ứng của rs1801133. Khảo sát các đặc tính kỹ thuật của quy trình như độ đặc hiệu kỹ thuật, độ lặp lại, độ tái lập cho kết quả tốt. Cuối cùng, quy trình realtime PCR HRM phân type rs1801133 trên 100 DNA mẫu lâm sàng có so sánh một phần với kỹ thuật giải trình tự nucleotide Sanger. Kết quả thu nhận được cho thấy quy trình phân type hiệu quả rs1801133 được áp dụng trên các mẫu thực tế, vì vậy quy trình này có thể được ứng dụng để phân type rs1801133 trong thực tế lâm sàng.

Tù khóa-rs1801133, real-time PCR HRM, SNP, MTHFR 